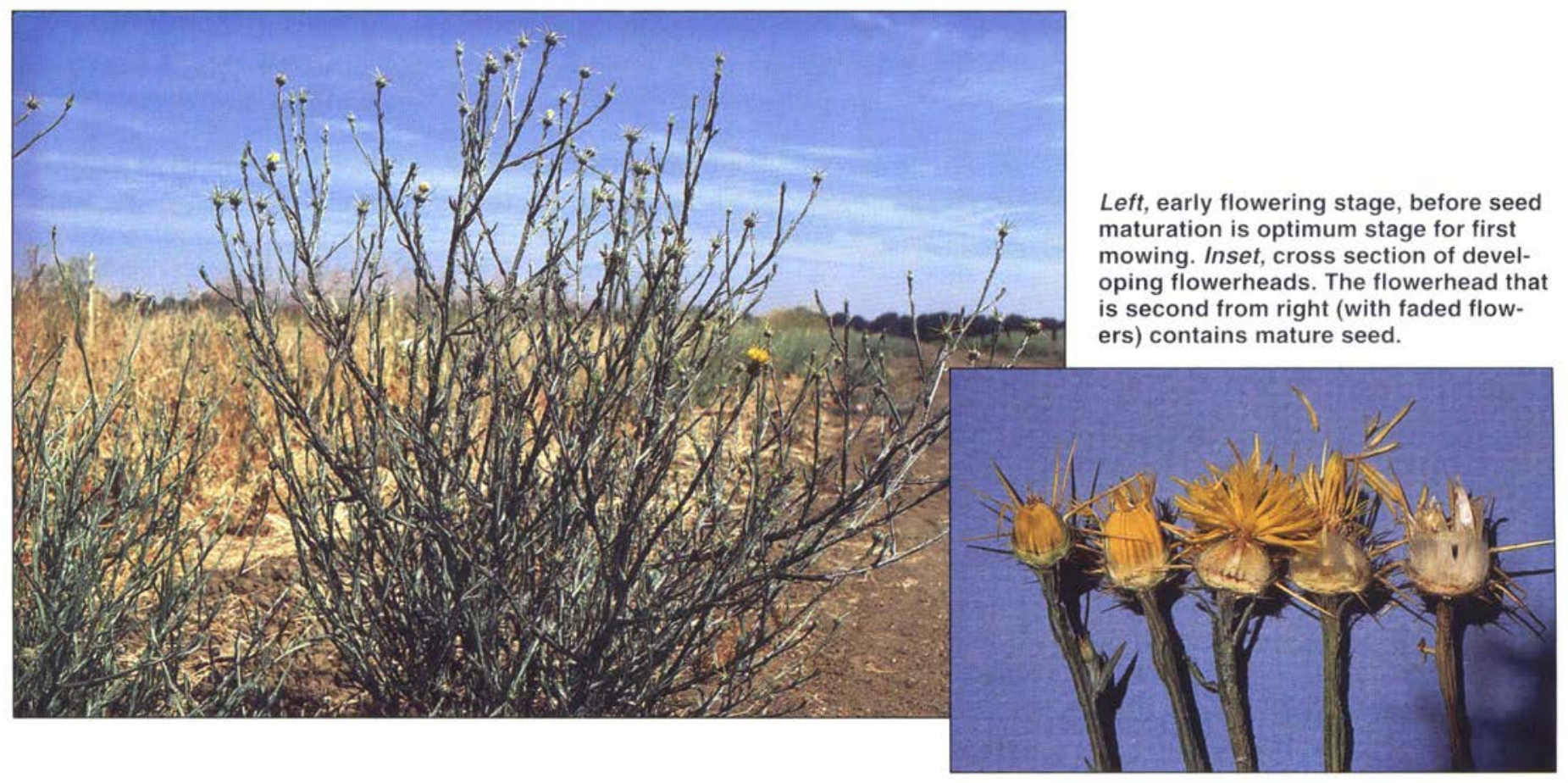

\title{
Mowing and subclover plantings suppress yellow starthistle
}

\author{
Craig D. Thomsen $\square$ Marc P. Vayssières $\square \quad$ William A. Williams
}

Yellow starthistle, a plant pest introduced to California in the mid1800s, has infested more than 10 million acres and continues to spread. Vegetation managers, producers and land owners are searching for control methods that are compatible with their various land uses. Mowing and competitive plantings are two options that can be useful in yellow starthistle management programs. Timing is important. If mowing occurs too early, yellow starthistle can take advantage of the reduced competition for space, light and water. If it is done too late, large quantities of seed will disperse and replenish the seed bank. There were weed control benefits from planting subterranean clover as a competitive plant in combination with mowing, but the tested varieties declined substantially.
Yellow starthistle is one of the most serious exotic plant pests in California. It was introduced in the mid-1800s and has now infested more than 10 million acres, according to the latest estimates. Yellow starthistle is toxic to horses, and its spines and ability to form dense stands impede access to the land. Because it grows in the summer and achieves high densities, it threatens the survival of native summeractive plants. The abundant biomass it produces increases the fire hazard at the end of summer. Despite its extensive distribution, it has not reached its geographical limits and continues to spread statewide.

The results of our earlier grazing experiments provided evidence that defoliation at later stages of growth (bolting, pre-spiny stage) did more damage to the plants and resulted in better control than defoliation at the earlier rosette stages (Thomsen et al. 1993). We became interested in mow- ing because it allows yellow starthistle to be defoliated at an even later stage than grazing, since the development of spines is not a limitation for mowing as it is for grazing. We anticipated that the effect of defoliation would be more severe when the plants were flowering. However, if mowing occurred in late flowering, the production and dispersal of viable seeds would prevent the long-term control of yellow starthistle.

Biocontrol researcher Don Maddox described the growth stages of yellow starthistle, Centaurea solstitialis L., and noted that yellow starthistle seeds become viable when the flowerhead fades, turning from a conspicuous bright yellow to a dull straw color. Therefore we targeted our late-season mowing to the stage at which the first bright yellow flowers appear but before any fading occurs. At this stage most of the flowerheads are still in the spiny bud stage and brightly pigmented flowers constitute a very small 
proportion of the total. We characterized this early flowering stage by sampling on June 10,1992, at the Agronomy Farm site described in the next section. Out of a total of 1,800 flowerheads counted, about $98 \%$ were in the spiny bud stage, $1.4 \%$ were at the bright yellow stage, $0.5 \%$ were at the faded stage and only $1(0.06 \%)$ had viable seeds.

\section{Agronomy Farm experiment}

A mowing experiment was carried out for 3 years (1992-1994) on annual grassland vegetation infested by yellow starthistle on the Agronomy Farm at UC Davis. We compared early-season and late-season mowing regimes for their ability to suppress yellow starthistle's reproductive output. We used a randomized complete-block design to control an existing gradient in the severity of the infestation.

The treatments were (1) a single early mowing at the bolting stage (late April to early May); (2) a single late mowing at the early flowering stage (mid-June); (3) late mowing at the early flowering stage, as in treatment 2 , followed by a second mowing at early flowering on regrowth (late July to early August); (4) two late mowings as in treatment 3 , but with manual removal of the yellow starthistle plants that regrew after the second mowing (in 1993 and 1994 only); and (5) unmowed control. Each treatment was represented in each of the four blocks. Treatment plots were 30 by 30 feet ( 9 by 9 meters) and were randomly assigned over the much larger treatment paddocks of our previous grazing experiment. Mowing was done with a flail mower mounted on a small tractor, and the mowed material was left in place.

To evaluate the effect of the mowing treatments, we monitored yellow starthistle flowerhead and seedling densities. Flowerhead densities are an indicator of seed production per unit area, and seedling densities are an expression of the size of the seed bank. These densities were estimated by counting the number of flowers or seedlings that occurred in a 13.7-inch diameter $\left(0.1 \mathrm{~m}^{2}\right)$ circular frame. We took 12 counts in each plot at locations determined in advance on a systematic grid. This sampling protocol satisfies randomization requirements while allowing us to directly compare seedling counts to flowerhead counts at each of the individual sampling locations. We sampled once for flowerhead densities in August-September and once for seedling densities after germination in November-December. Actual sampling dates depended on the regrowth after treatment and on the yearly rainfall pattern for seedling emergence. Each year we gathered 240 counts of flowerheads ( 5 treatments by 4 blocks by 12 samples) and 240 counts of seedlings, with the exception of the first year, when we sampled seedlings in only two of the blocks.

Our data involved small wholenumber counts with many zero values in three of the treatments. Such data follows a Poisson distribution and violates the basic assumptions of analysis of variance. To remedy this situation, we transformed the data by ranking them before computing the ANOVAs, a practice established by Conover and Iman and implemented in the SAS statistical package. The treatment means of the rank-transformed data were compared by means of the classic LSD method. Although analyses were computed on rank-transformed data, the actual densities (number $/ \mathrm{m}^{2}$ ) are reported to ensure a meaningful interpretation.

Initially, each year was analyzed independently of the others, and flowerhead densities were analyzed independently from the seedling densities of the same year (table 1). Next, the 3 years of data were analyzed conjointly, using the appropriate splitblock design, to test for a year effect. We also investigated the relationship between seedling emergence and seed production by regressing the individual seedling counts on the corresponding flowerhead counts, using the 960 counts gathered in the 1993 and 1994 seasons. We obtained precipitation data from the weather station on the Agronomy Farm. Experiment-wide infestation levels by growing season were computed as the average of all flowerhead counts across all treatments, including the control.

\section{Agronomy Farm results}

Early mowing did not reduce yellow starthistle seed output and seedbank size in any of the 3 years (table 1 ). In fact, early mowing in 1993 significantly increased flowerhead densities and subsequent yellow starthistle germination when compared to the control. Late mowing reduced yellow starthistle seed output and seedling densities in each of the 3 years. Plots that received a single late mowing had consistently lower densities of flowerheads and seedlings than the control. Each year, a second mowing provided an additional reduction in flowerhead densities when compared to a single

\begin{tabular}{|c|c|c|c|}
\hline & $\begin{array}{c}\text { First year } \\
1992^{*}\end{array}$ & $\begin{array}{c}\text { Second year } \\
1993\end{array}$ & $\begin{array}{c}\text { Third year } \\
1994\end{array}$ \\
\hline \multirow[t]{2}{*}{ Treatment } & \multicolumn{3}{|c|}{ Flowerheads (summer) } \\
\hline & \multicolumn{3}{|c|}{ number/meter ${ }^{2}$} \\
\hline Control & 326 at & $459 \mathrm{~b}$ & $223 \mathrm{a}$ \\
\hline Early mowing & $381 \mathrm{a}$ & $713 \mathrm{a}$ & 226 a \\
\hline One late mowing & $46 \mathrm{~b}$ & $169 c$ & $74 \mathrm{~b}$ \\
\hline Two late mowings & $19 \mathrm{c}$ & $30 \mathrm{~d}$ & $1 \mathrm{c}$ \\
\hline Two late mowings and removal & $\mathrm{n} / \mathrm{a}$ & $\mathrm{n} / \mathrm{a}$ & $19 c$ \\
\hline Treatment & \multicolumn{3}{|c|}{ Seedlings (fall) } \\
\hline Control & 3,369 a & $1,934 \mathrm{~b}$ & $1,529 a b$ \\
\hline Early mowing & $5,338 \mathrm{a}$ & $5,538 \mathrm{a}$ & $2,498 \mathrm{a}$ \\
\hline One late mowing & $356 \mathrm{~b}$ & $516 \mathrm{c}$ & $397 \mathrm{~b}$ \\
\hline Two late mowings & $183 \mathrm{~b}$ & $37 \mathrm{~d}$ & $23 c$ \\
\hline Two late mowings and removal & $\mathrm{n} / \mathrm{a}$ & $42 d$ & $20 \mathrm{c}$ \\
\hline \multicolumn{4}{|c|}{$\begin{array}{l}\text { - In } 1992 \text { seedlings were counted in only two of the four blocks of the experiment. Therefore, the seedling } \\
\text { densities reported for } 1992 \text { are not directly comparable to the other values in this table. All other densities in } \\
\text { this table are directly comparable across years and seasons. To convert to number/feet }{ }^{2} \text {, multiply by } 0.093 \text {. } \\
+ \text { Within a given year, treatment means followed by different letters are significantly different (P }<5 \% \text { ). Sta- } \\
\text { tistics were computed on rank-transformed data. }\end{array}$} \\
\hline
\end{tabular}


late mowing. The seedling density of yellow starthistle in the two-latemowings plots was significantly lower than in the single-late-mowing plots, except in the first year. Finally, manually removing the few yellow starthistle plants that survived two late mowings did not result in a significant reduction in subsequent seedling densities in the 2 years it was done.

An estimate of the number of seeds per flowerhead was obtained by random sampling of 48 flowerheads in the control plots. The number of seeds per flowerhead varied from 30 to 96 , with an average of 54 . Analysis of count data at the 240 individual sampling locations over 2 years showed a strong relationship between number of flowerheads and number of seedlings. Overall, flowerhead counts explained $72 \%$ (as measured by the regression $R^{2}$ ) of the variation in subsequent germination at the same location.

\section{Proper timing is important}

This experiment demonstrates that proper timing is an important condition in the successful use of mowing in yellow starthistle management. Our results demonstrate that mowing can reduce but can also increase infestations, depending on when it is done. These contrasting results are consistent with those of our previous grazing experiments. Early grazing (at the rosette stage) by livestock increased yellow starthistle density, whereas late grazing (at the bolting, pre-spiny stage) significantly decreased flowerhead and seedling densities.

In this experiment, a single late mowing at the early flowering stage consistently reduced yellow starthistle's reproductive output. But a subsequent mowing, again at the early flowering stage, further reduced seed production. Although the first year's seedling numbers were not significantly different between the two-latemowings and the single-late-mowing treatments, they were strikingly different the following 2 years.

The buffering effect of an established seed bank probably explains the lack of response noted in the first year. In support of this explanation, flowerhead numbers were significantly different between these two treatments right from the first year. Although most yellow starthistle seeds germinate within a year of dispersal, other investigators (Jolery et al.

1992) have demonstrated that a proportion of seeds can survive for several years in the soil. Therefore an initial reduction in flowerhead density and seed output may not be followed by a commensurate reduction in seedling emergence. To substantially reduce the level of infestation, it is necessary to reduce seed production consistently for several years.

The same buffering effect could also explain why 2 years of manual removal of the few plants that survived two late mowings did not significantly reduce seedling densities beyond those of the two-late-mowings treatment. Seed dispersal from adjacent plots might also be involved in this case, although Roche (1992) at Washington State University demonstrated that most yellow starthistle seeds fall within 2 feet of the parent plant. Based on these results, the complete eradication of yellow starthistle from a particular location is likely to require several years without any seed production or introduction.

The conjoint analysis of the 3 years of yellow starthistle data reveals a highly significant year effect. Experiment-wide yellow starthistle flowerhead density was much higher in the Sept. 1992-Aug. 1993 growing season than in the other two seasons of experimentation, with 280 flowers $/ \mathrm{m}^{2}$ in 1992-1993 versus 158 flowers $/ \mathrm{m}^{2}$ in 1991-1992 and 108 in 1993-1994 (fig. 1). Average flowerhead densities in the control treatment alone (not shown) reflect the same trends.
Compared to the unmowed control on the left, early mowing increased yellow starthistle densities and subsequent germination.

Interestingly, the pattern of precipitation at the Agronomy Farm is very similar to that of starthistle densities (17.4 inches in 1991-1992; 29.6 inches in 1992-1993; 11.9 inches in 1993-1994; fig. 1). Furthermore, June 1993 was unusually wet, with 1.5 inches of rainfall. Other research has indicated that yellow starthistle's reproductive output is higher in years with greater amounts of rainfall (Sheley and Larson 1994). Our observations support these findings. Our hypothesis is that in wetter years, water accumulates in deeper soil layers accessible to yellow starthistle's deep taproot but generally not available to shallow-rooted annual grasses. Late-season rainfall replenishes soil moisture at a time when yellow starthistle is still growing, whereas most annual grassland plants have already completed their life cycles and died. Both these factors favor yellow starthistle summer growth and reproduction. By suppressing or removing competitors during a period when they are still intensely competing for resources, early mowing allows yellow starthistle to take advantage of the extra water. This would explain why in some years early mowing actually increases yellow starthistle infestation. For example, although "early mowing" in this experiment occurred 


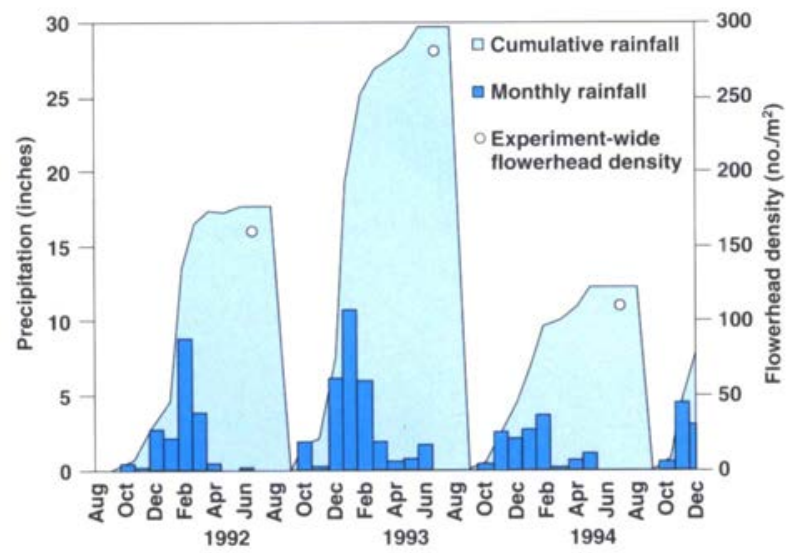

Fig. 1. Precipitation and yellow starthistle flowerhead density, UC Davis 1992-1994.

at a later phenological stage than the "early grazing" in our previous work, the early mowing treatment still resulted in a significant increase in weed infestation in the wettest of the 3 years.

\section{Planting clover and mowing}

The mowing research at the Agronomy Farm demonstrated that timed mowing can significantly reduce yellow starthistle, but additional measures are needed to enhance control and prevent seed recruitment. Therefore the second experiment was designed to test the effectiveness of combining plantings of subterranean clover, or subclover (Trifolium subterraneum), and mowing to further suppress yellow starthistle.

The choice of a successful plant competitor should reflect the biological attributes of the pest plant, ecological conditions and the future use of the site. In the case of yellow starthistle, it appears that an appropriate competitive species should be capable of reducing light to yellow starthistle in the fall and winter during the seedling and rosette stages and/or use considerable soil moisture and nutrients in late spring and summer.

Subclover cultivars have been used for many years in California as a highprotein forage and as a nitrogen-fixing cover crop in orchards and vineyards. There are early-, mid- and late-season varieties that provide an opportunity for selecting cultivars for local climates and production systems. Characteristics that make some cultivars competitive include strong winter and spring growth, large leaf area, ability to recover after defoliation and flowers produced below mowing and herbivory heights.

In other research in which we tested dryland legumes as forage and cover crops, we observed that some subclover varieties suppressed yellow starthistle when stands were mowed in late winter or early spring.

Subclover performance is enhanced by early mowing because the shading influence from tall annual grasses is reduced. Subclover regrows relatively quickly during this active growth period, and some varieties can form a dense network of interwoven stems and leafy canopies that reduce sunlight to associated yellow starthistle rosettes. However, yellow starthistle is deeper rooted and matures 1 to 3 months after subclover. Therefore relying on competition from subclover plantings alone is insufficient, and late spring or early summer mowings are required to further reduce the survival of yellow starthistle.

\section{BIRC Field Station experiment}

The second experiment is located at the Bio-Integral Resource Center (BIRC), 6 miles west of Winters in a foothill ecosystem. The soil is mapped as a Dibble-clay loam, a soil that is typical of pastures and occasionally orchards and dryfarmed small grains. The vegetation is dominated by yellow starthistle, annual grasses and lesser amounts of exotic and native forbs. We divided a portion of an undeveloped pasture into 12 15-by-25-foot plots for the following three treatments: (1) subclover seeding with mowing; (2) mowing with no subclover; and (3) control with no subclover seeding or mowing. The treatments were replicated four times in a randomized complete-block design. We prepared a seed bed by tilling the plots with a disk and harrow on June 13, 1993, to take advantage of a late spring rain that had moistened the soil. We disked the entire experimental area before any yellow starthistle seeds were produced.

On Oct. 9, 1993, we broadcast a 1:1 mixture of the subclover varieties 'Koala' and 'Karridale' at $40 \mathrm{lb} /$ acre and lightly raked the soil to cover the seed. Prior to seeding, we inoculated the seeds with suitable legume bacteria and applied fertilizer - phosphorus at $100 \mathrm{lb} /$ acre and sulfur at $136 \mathrm{lb} /$ acre (repeated in 1995). A germinating rain occurred on Oct. 13.

Each year the seeded plots were mowed (3-inch mowing height) in February to enhance clover growth. These plots and the mowed-only plots were mowed yearly in June to defoliate yellow starthistle in the early flowering stage before any flowers had faded - that is, at the same stage of development described previously for the Agronomy Farm experiment. The first year these treatments plots were mowed again on July 24 to remove yellow starthistle regrowth and reduce seed production. Thereafter these plots were mowed only once in the summer (June) to allow us to better measure the effects of competition from the subclover.

Treatment effects were measured each year by sampling flowerhead densities with a 13.7-inch-diameter $\left(0.1 \mathrm{~m}^{2}\right)$ circular sampling frame to measure reproductive potential. Seedling densities were counted in November 1996 to measure the cumulative treatment effects on the seed bank.

BIRC Field Station results. There were large reductions in yellow starthistle in both seeded and unseeded mowing treatments in each year (table 2). First-year results suggest that there was no additional yellow starthistle suppression in the subclover treatments. However, whatever competitive effect there may have been from the subclover the first year would have been negated by the second mowing in July, which effectively eliminated most of the yellow starthistle in both treatments. In the second and third years, 1995 and 1996, when we mowed only once in the bolting stage, better control was achieved in the subclover treatment than in the unseeded plots.

Second- and third-year results show a decrease in yellow starthistle in the 
subclover plots compared to the unseeded treatments. In the third year no yellow starthistle flowerheads were detected in the subclover plots. This decrease was also reflected in the yellow starthistle seedling density; there were 10 times the number of seedlings in the unseeded mowed plots as in the subclover plots.

To measure subclover regeneration, subclover seedling densities were counted in the third and fourth years of growth. Third-year subclover seedling densities were measured at 260 seedlings $/ \mathrm{ft}^{2}$ $\left(2,800 / \mathrm{m}^{2}\right)$, and fourth-year densities were 80 seedlings $/ \mathrm{ft}^{2}\left(860 / \mathrm{m}^{2}\right)$. This is the equivalent of 172 and 53 pounds (194 and $60 \mathrm{~kg} / \mathrm{ha}$ ) of viable subclover seed per acre. This can be compared to the initial seeding rate of 40 pounds per acre.

BIRC Field Station discussion. The results demonstrated that there were weed control benefits from the subclover plantings. The vigorous growth and dense spring canopies produced each year by subclover helped suppress yellow starthistle growth. With fewer and presumably weaker yellow starthistle plants remaining in the spring from the subclover competition, a single lateseason mowing dramatically reduced yellow starthistle reproductive output the second year and completely eliminated seed production the third year. It appears that most of the yellow starthistle seeds in the seed bank here were eliminated in 4 years by a control program that allowed only minimal recruitment of new seed.

The results from the mowing without subclover seeding treatment are generally consistent with those obtained from previous work at the Agronomy Farm. Mowing yellow starthistle in the early flowering stage decreased canopy size and reproductive output and led to lower plant densities. Both sites support annual grassland species that probably provided some competition against yellow
Late mowing at the early flowering stage, followed by a second mowing at early flowering on regrowth, on right, significantly reduced flowerhead and seedling densities compared to the unmowed control on the left.

starthistle. In tall, dense stands of annual grasses, yellow starthistle seedlings etiolate and the rosettes have fewer leaves. Plants in the rosette stage tend to be upright rather than prostrate. Under these conditions, yellow starthistle is probably more susceptible to damage from mowing later in its life cycle than where there is less competition and more available sunlight.

As other research has shown, the timing and amount of rainfall also influence the ability of yellow starthistle to regrow and reproduce. Therefore the degree of control that one can expect with mowing varies from season to season. Site-to-site differences such as variation in soil depth and waterholding capacity also affect yellow starthistle response to mowing. Some of these factors probably explain the differences in treatment responses between the sites. For example, two lateseason mowings in unseeded plots the first year at the BIRC Field Station produced much better control in 2 of the 3 years at the Agronomy Farm under the same treatment. Much better control was obtained at the BIRC Field Station with one late-season mowing than with a single late-season mowing at the Agronomy Farm.

\section{Subclover cultivar selection}

The subclover mix 'Koala' and 'Karridale' selected for this study was based on the performance of 66 annual legume varieties (including Trifolium spp.-subterranean, rose, cupped, crimson, berseem, balansa and strawberry clovers; Medicago spp.- - bur, barrel and snail medics; Vicia spp.-lana, purple and common vetches; Lotus purshianus-Spanish clover; and Lupinus nanus - lupine) tested in a sheep-grazed dryland pasture at the BIRC Field Station the year before this research began. The testing was initiated because BIRC personnel were looking for site-adapted legumes that could be used for weed control and forage and as a nitrogen source to enhance soil fertility. As a group the subclovers ( 26 were screened) far outperformed the other entries.

We selected the cultivars 'Koala' and 'Karridale' for the yellow starthistle experiment because they were among the top-producing entries (95\% canopy cover at peak standing crop) the first year of the trial and seeds are commercially available. However, 2 years later they had both declined substantially ('Koala', 45\%

TABLE 2. Yellow starthistle flowerhead (summer 1994, 1995, 1996) and seedling (fall 1996) densities under mowing and subclover seeding, BIRC Field Station

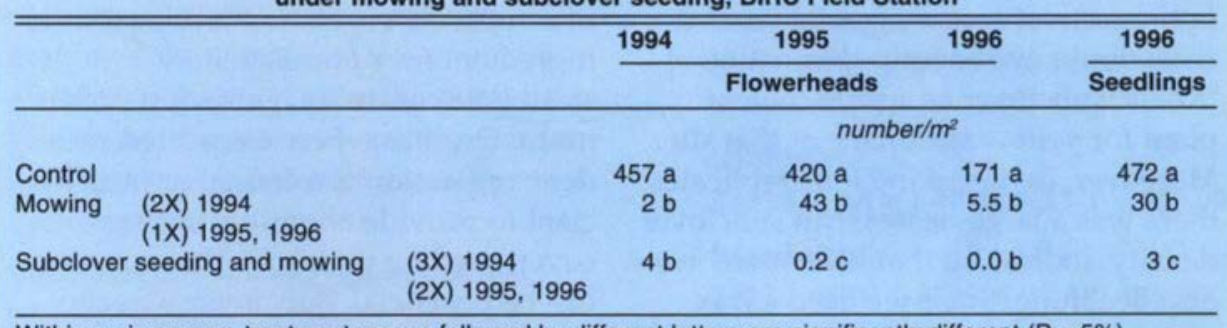

Within a given year, treatment means followed by different letters are significantly different $(P<5 \%)$. Statistics were computed on log-transformed data. 


\section{information you need!}

\section{From the University of California's Division of Agriculture and Natural Resources}

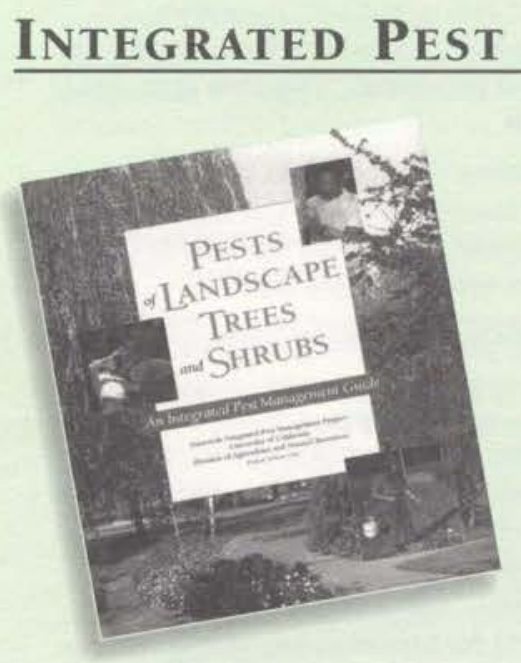

"a complete and sensible approach to controlling pests..."

-Publishers Weekly

"the most thorough, balanced, and non-judgmental treatment of pests in the landscape..."

-Pacific Horticulture

\section{Our \#1 Best Seller! \\ Pests of Landscape Trees and Shrubs}

This is the most comprehensive and authoritative book ever produced on managing landscape pests and an indispensable resource for professional landscape managers and home gardeners. The authors are UC Integrated Pest Management experts, and they use hundreds of outstanding illustrations, including more than 300 detailed color photographs, as they emphasize environmentally safe, less-toxic IPM methods of pest control. Professional and lay readers alike can use the 50 pages of problemsolving tables to find specific damage symptoms, and then follow the tables' page references to learn how to control the pests causing the damage. $336 \mathrm{pp}$.

\section{ISBN 1-879906-18-X \$32.00}

Companion slide set, 317 slides.

$94 / 104 \$ 268.60$

See next page for more IPM titles.

\section{FOOD AND NuTRITION}

\section{Pirámide del día con el sabor popular Mexicano - A Food Guide Pyramid with a Mexican Flavor}

Poster and video in Spanish and English. Here's a new poster and video presentation of the USDA Food Guide Pyramid that addresses lifestyle, health issues, and dietary practices that are unique to Mexican-American culture. The food pyramid is introduced here

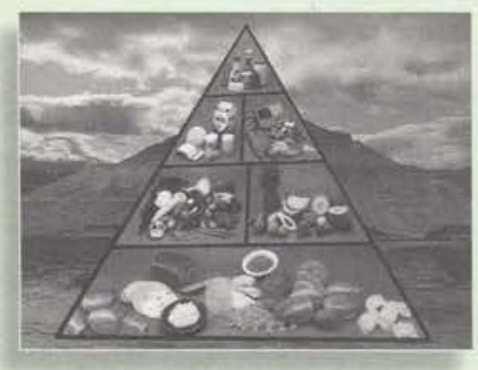

in terms of the pyramids of Mesoamerica in a presentation that emphasizes the traditional core diet of corn, beans, squash, and chiles and the hard work ethic common to past and present Latino families.

VIDEO: English $14 \mathrm{~min}$., Spanish $16 \mathrm{~min}$. V97-B $\$ 25.00$

POSTER: $17 " \times 22$ ", full color $21566 \$ 5.00$
As a new service, California Agriculture will periodically carry a pull-out insert like this one listing publications, slide sets, and videos available from Communication Services, an office of UC Division of Agriculture and Natural Resources. We hope this service will be a welcome convenience. Let us know what you think: call us at 510-987-0044 or e-mail calag@ucop.edu.

-Editor

\section{FARMing GuIdes}

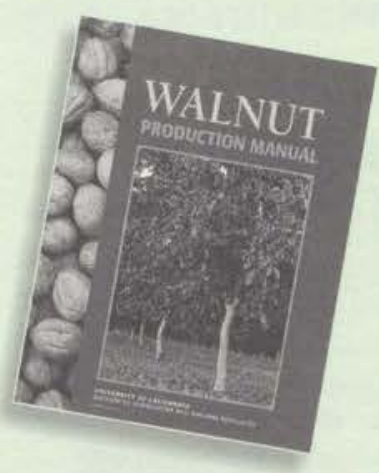

\section{Walnut Production Manual}

This long-awaited revision of our 1985 classic Walnut Orchard Management is the only complete guide available covering all aspects of walnut culture. Applicable worldwide, the book provides growers and researchers a basic understanding of the growth, development, and function of the walnut tree and nut, as well as practical considerations on walnut culture, pest management, harvesting, and handling. More than 60 UC authors give you the latest information on walnut varieties, hedgerow planting, and agricultural chemicals, and cover everything from the crop's ancient origins to its increasingly global market. Plenty of detailed color photos. 328 pp.

Hardcover

3373 H ISBN 1-879906-33-3 \$50.00 Paperbound

3373 ISBN 1-879906-27-9 \$35.00

See next page for more farming titles. 
2.85

\section{Integrated Pest MAnagement}

\section{Pests of the Garden and Small Farm}

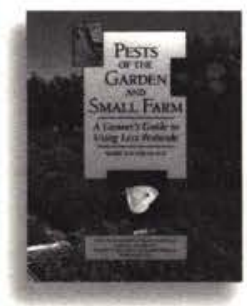

Practical, useful techniques to help backyard fruit and vegetable growers and farmers of small acreages use fewer toxic pesticides, more

biological controls, and other alternative approaches to reduce pests. With 250 color photos, 90 line drawings, and 28 black-and-white photos. 1990 , $286 \mathrm{pp}$.

3332 ISBN 0-931876-89-3 \$30.00

\section{Grape Pest Management Second Edition}

This is the guide to pest control for the grape industry. This edition includes control strategies for the variegated grape leafhopper and IPM strategies for control of all major grape diseases and pests. More than 400 detailed color photos. 1992, $412 \mathrm{pp}$.

3343 ISBN 0-931876-96-6 \$70.00

\section{FARMing GuideS}

\section{Production Manuals}

Thorough, practical manuals that offer valuable information to commercial growers of these commodities worldwide. Major sections cover the crops' botany and history, domesticated varieties, orchard or vineyard planning, irrigation requirements, pest control, harvesting, and postharvest handling and processing.

Almond Production Manual. 1996
3364 ISBN 1-879906-22-8 $\$ 30.00$
Cotton Production Manual. 1996
3352 ISBN 1-879906-09-0 $\$ 55.00$
Kiwifruit Growing and Handling. 1994
$3344 \quad$ ISBN 1-879906-04-X $\$ 25.00$
Olive Production Manual. 1994
3353 ISBN 1-879906-15-5 $\$ 30.00$
Peaches, Plums, and Nectarines:
Growing and Handling for Fresh
Market. 1989
$3331 \quad$ ISBN 0-931876-88-5 $\$ 42.50$
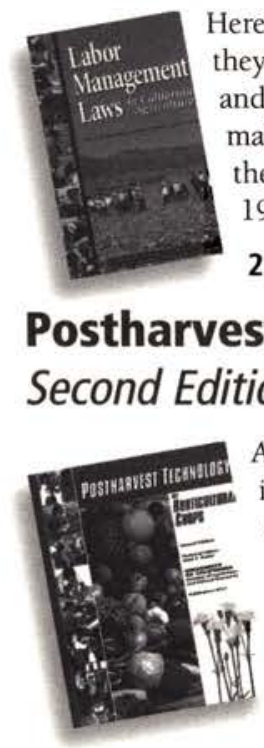

\section{IPM Manuals}

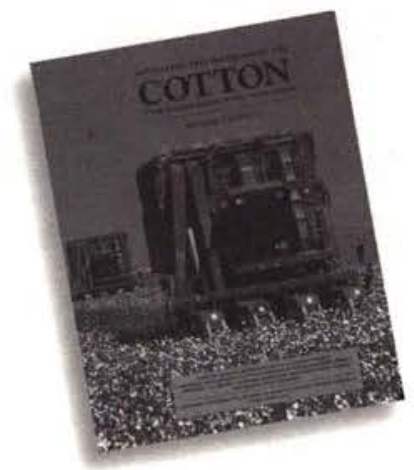

NEW! Request our free catalog of more than 700 books, color slide sets, and videos. Call 1-800-994-8849, or e-mail danrcs@ucdavis.edu.

Comprehensive chapters on insects and mites, pathogens, weeds, nematodes, and vertebrates cover pest identification, biology, and management. Monitoring methods, treatment thresholds, biological controls, and cultural practices are thoroughly explained. All IPM manuals feature superbly detailed color photographs and line drawings.

A complete set of color slides is also available for each manual. Call for information.

IPM for Alfalfa Hay. 1981

3312 ISBN 0-931876-48-6 \$22.00

IPM for Almonds. 1985

3308 ISBN 0-931876-73-7 \$22.00

IPM for Apples and Pears. 1991

3340 ISBN 0-931876-94-X \$30.00

IPM for Citrus-SECOND EDITION. 1991

3303 ISBN 0-931876-98-2 \$25.00

IPM for Cole Crops and Lettuce.

Revised 1992

3307 ISBN 0-931876-70-2 \$22.00

IPM for Cotton in the Western Region of the United States-SECOND EDITION. 1996 3305 ISBN 1-879906-30-9 \$30.00

\author{
IPM for Potatoes in the Western United \\ States. Revised 1992 \\ 3316 ISBN 0-931876-74-5 \$22.00 \\ IPM for Rice-SECOND EDITION. 1992 \\ 3280 ISBN 1-879906-11-2 \$22.00 \\ IPM for Small Grains. 1990 \\ 3333 ISBN 0-931876-91-5 \$22.00 \\ IPM for Strawberries. 1994 \\ 3351 ISBN 1-879906-08-2 \$30.00 \\ IPM for Tomatoes-FOURTH EDITION. 1997 \\ 3274 ISBN 1-879906-32-5 $\$ 30.00$ \\ IPM for Walnuts-SECOND EDITION. \\ Revised 1993 \\ 3270 ISBN 0-931876-50-8 \$22.00
}

\section{Labor Management Laws in California Second Edition}

Here's a compact, integrated guide to U.S. and California regulations as they relate to labor management in agriculture. This book tells managers and employees about the laws that apply directly to them, and helps lawmakers, public agency staff, and interested observers better understand the nature of existing legal influences on farm business operations. $1995,188 \mathrm{pp}$.

21404 ISBN 1-879906-29-5 \$20.00

\section{Postharvest Technology of Horticultural Crops Second Edition}

As much as $25 \%$ of all produce harvested in the United States each year is lost to spoilage or mechanical damage before it can reach the consumer. In some countries, losses can range up to $50 \%$ of the crop. This book is a guide to implemention of the most effective measures available for preventing damage and spoilage of farm produce-ornamentals, herbs, fruits, nuts, and vegetables —on the way to market. Color and black-and-white photographs. 1992, 304 pp.

3311 ISBN 0-931876-99-0 \$50.00 


\section{To place an order}

To order, just tear out the order form at right,

fill it in, and mail it with payment to

\section{University of California \\ DANR Communication Services \\ 6701 San Pablo Avenue \\ Oakland, CA 94608-1239}

Send e-mail inquiries to danrcs@ucdavis.edu.

- Payment must accompany your order. Please make check or money order payable to UC Regents. You may also order by telephone (1-800-994-8849 or 510-642-2431) or Fax (510-643-5470) using a purchase order. MasterCard, or VISA. Minimum order $\$ 5$ for credit cards, $\$ 25$ for purchase orders. Discounts apply to purchases of 10 or more copies of a single title-call or write for details.

- California customers add $8.25 \%$ sales tax to the Merchandise Total

- International customers, please request a pro forma invoice via telephone, Fax, mail, or email. Indicate the title, product number, and number of copies desired for each item, as well as the mode of shipment (surface mail or airmail). We will send you a pro forma invoice indicating the exact price of the ordered items and all postage and handling charges. Payment in U.S. dollars through a bank located in the United States is required before orders are shipped. Make checks or money orders payable to UC Regents. International customers may also pay for orders using VISA or MasterCard.

- If for any reason you are dissatisfied with your purchase, you can return it in salable condition within 90 days for refund or for credit against the purchase of another item from our catalog. Returns are subject to a $10 \%$ restocking fee.

- Prices and policies are subject to change without notice.

- Please allow two weeks for delivery.

Shipping Table (to U.S. addresses) Merchandise Total Shipping Charge

\begin{tabular}{cc}
$\$ 5-\$ 9.99$ & $\$ 2.00$ \\
\hline$\$ 10-\$ 19.99$ & $\$ 3.00$ \\
\hline$\$ 20-\$ 29.99$ & $\$ 4.00$ \\
\hline$\$ 30-\$ 39.99$ & $\$ 5.00$ \\
\hline$\$ 40-\$ 49.99$ & $\$ 6.00$ \\
\hline$\$ 50-\$ 79.99$ & $\$ 7.00$ \\
\hline$\$ 80-\$ 99.99$ & $\$ 8.00$ \\
\hline$\$ 100$ or more & $\$ 10.00$ \\
\hline
\end{tabular}

\section{Teaching a Class?}

We offer quantity discounts starting at $20 \%$ for 10 or more copies of a single title. For details or to order, call toll-free 1-800-994-8849.

\section{Order Now,}

\section{or Check Here $\square$ to Receive Our Free Catalog}

\begin{tabular}{|c|c|c|c|c|}
\hline Title & $\begin{array}{l}\text { Item } \\
\text { no. }\end{array}$ & $\begin{array}{l}\text { No. of } \\
\text { copies }\end{array}$ & Unit price : & $=$ Total price \\
\hline Pests of Landscape Trees and Shrubs & 3359 & & $\$ 32.00$ & \\
\hline Companion slide set & 94/104 & & $\$ 268.60$ & \\
\hline Pests of the Garden and Small Farm & 3332 & & $\$ 30.00$ & \\
\hline Grape Pest Management-SECOND EDITION & 3343 & & $\$ 70.00$ & \\
\hline IPM for Alfalfa Hay & 3312 & & $\$ 22.00$ & \\
\hline IPM for Almonds & 3308 & & $\$ 22.00$ & \\
\hline IPM for Apples and Pears & 3340 & & $\$ 30.00$ & \\
\hline IPM for Citrus-SECOND EDITION & 3303 & & $\$ 25.00$ & \\
\hline IPM for Cole Crops and Lettuce & 3307 & & $\$ 22.00$ & \\
\hline $\begin{array}{l}\text { IPM for Cotton in the Western } \\
\text { United States-SECOND EDITION }\end{array}$ & 3305 & & $\$ 30.00$ & \\
\hline $\begin{array}{l}\text { IPM for Potatoes in the Western } \\
\text { United States }\end{array}$ & 3316 & & $\$ 22.00$ & \\
\hline IPM for Rice-SECOND EDITION & 3280 & & $\$ 22.00$ & \\
\hline IPM for Small Grains & 3333 & & $\$ 22.00$ & \\
\hline IPM for Strawberries & 3351 & & $\$ 30.00$ & \\
\hline IPM for Tomatoes-FOURTH EDITION & 3274 & & $\$ 30.00$ & \\
\hline IPM for Walnuts-SECOND EDITION & 3270 & & $\$ 22.00$ & \\
\hline Walnut Production Manual (hardbound) & 3373H & & $\$ 50.00$ & \\
\hline Walnut Production Manual (paper) & 3373 & & $\$ 35.00$ & \\
\hline $\begin{array}{l}\text { Labor Management Laws in } \\
\text { California-SECOND EDITION }\end{array}$ & 21404 & & $\$ 20.00$ & \\
\hline $\begin{array}{l}\text { Postharvest Technology of Horticultural } \\
\text { Crops-SECOND EDITION }\end{array}$ & 3311 & & $\$ 50.00$ & \\
\hline Almond Production Manual & 3364 & & $\$ 30.00$ & \\
\hline Cotton Production Manual & 3352 & & $\$ 55.00$ & \\
\hline Kiwifruit Growing and Handling & 3344 & & $\$ 25.00$ & \\
\hline Olive Production Manual & 3353 & & $\$ 30.00$ & \\
\hline $\begin{array}{l}\text { Peaches, Plums, and Nectarines: } \\
\text { Growing and Handling for Fresh Market }\end{array}$ & 3331 & & $\$ 42.50$ & s. \\
\hline $\begin{array}{l}\text { Pirámide del dia con el sabor } \\
\text { popular Mexicano (VIDEO) }\end{array}$ & V97-B & & $\$ 25.00$ & \\
\hline $\begin{array}{l}\text { Pirámide del dia con el sabor } \\
\text { popular Mexicano (POSTER) }\end{array}$ & 21566 & & $\$ 5.00$ & \\
\hline \multirow[t]{5}{*}{$\begin{array}{l}\text { ORDER VIDEO \& POSTER } \\
\text { TOGETHER AND SAVE }\end{array}$} & $21566 a$ & & $\$ 27.50$ & \\
\hline & \multicolumn{3}{|c|}{ Merchandise total } & \\
\hline & \multirow{2}{*}{\multicolumn{3}{|c|}{ Shipping (see shipping table) }} & \\
\hline & & & & \\
\hline & & & Total & \\
\hline
\end{tabular}

Name

Date

\section{Address}

City, State, ZIP

Country (if outside the USA)

$\square$ Check/Money order enclosed (payable to UC Regents)

$\square$ Purchase order enclosed. P.O. number

\section{$\square$ Bill my (check one) $\square$ MasterCard $\square$ VISA}

Card number

Exp. date 


$$
2^{\circ}
$$

\|l||

\section{BUSINESS REPLY MAIL FIRST-CLASS MAIL PERMIT NO 278 OAKLAND CA}

POSTAGE WILL BE PAID BY ADDRESSEE

UNIVERSITY OF CALIFORNIA

DIVISION OF AGRICULTURE \&

NATURAL RESOURCES

COMMUNICATION SERVICES

6701 SAN PABLO AVE STE 200

OAKLAND CA $94608-9887$

\section{II,I,ul,ul,II,III,II,II,}

\section{To fold order form} for mailing:

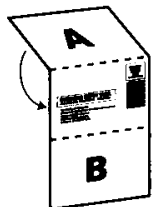

Fold Panel A.

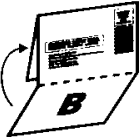

Fold Panel B.

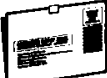

Tape closed at top.

Do not use staples.
NO POSTAGE

NECESSARY

IF MAILED

IN THE

UNITED STATES

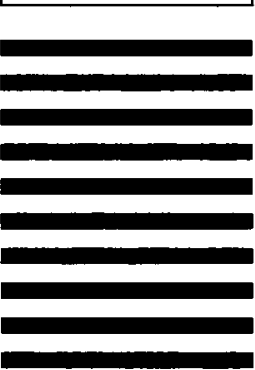

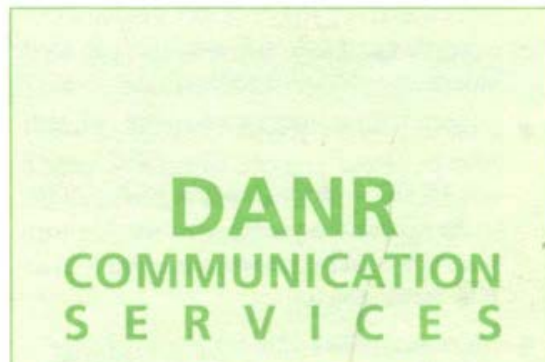

Division of Agriculture and Natural Resources

University of California

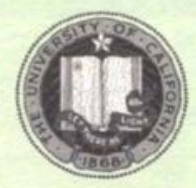

Phone: (800) 994-8849

FAX: (510) 643-5470

e-mail:

danrcs@ucdavis.edu

http://

danrcs.ucdavis.edu 